\title{
Association between duration of community-based group membership and sustainable livelihoods for Kenyan women dairy farmers
}

\author{
Colleen Walton ${ }^{\mathrm{a}, *}$, John VanLeeuwen ${ }^{\mathrm{a}}$, Fiona Yeudall ${ }^{\mathrm{b}}$, and Jennifer Taylor ${ }^{\mathrm{c}}$
}

Submitted 17 November 2011 / Revised 29 November 2011, 14 May 2012, 4 July 2012, and 18 July 2012 /

Accepted 26 July 2012 / Published online 4 October 2012

Citation: Walton, C., VanLeeuwen, J., Yeudall, F., \& Taylor, J. (2012). Association between duration of community-based group membership and sustainable livelihoods for Kenyan women dairy farmers. Journal of Agriculture, Food Systems, and Community Development, 3(1), 43-60. http://dx.doi.org/10.5304/jafscd.2012.031.002

Copyright (C) 2012 by New Leaf Associates, Inc.

Abstract

Kenyan community leaders called for strengthened sustainable livelihoods for farmers and in 1992 formed a self-help dairy group that was

a Centre for Veterinary Epidemiological Research, Atlantic Veterinary College, University of Prince Edward Island, 550 University Avenue, Charlottetown, PEI C1A 4P3 Canada.

b School of Nutrition, Centre for Studies in Food Security, Ryerson University, 350 Victoria Street Toronto, ON M5B 2K3 Canada.

c Department of Applied Human Sciences, University of Prince Edward Island, 550 University Avenue, Charlottetown, PEI C1A 4P3 Canada.

* Corresponding author: Colleen Walton; +1-902-566-0969; cwalton@upei.ca

Disclosures: Author Walton has been a volunteer milk quality advisor with WDL and has provided training for groups of WDL farmers. Author VanLeeuwen has provided animal health training for groups of WDL farmers with Canadian and Kenyan senior veterinary students. Authors Taylor, VanLeeuwen, and Walton are actively involved with Farmers Helping Farmers on a volunteer basis. reorganized in 2009 to form the Wakulima Dairy Ltd. (WDL). At WDL, members sell surplus milk to the dairy and, through nongovernmental organization (NGO) partnerships, receive training to enhance dairy farm productivity. As a result, higher milk production has been reported; however, data are lacking on sustainability and livelihood outcomes of dairy training for women farmers. To inform future projects and interventions, our study objectives were to determine the relationships between dairy group membership and duration of membership, sustainable livelihood assets, household income, and food security. We thus conducted a cross-sectional survey of 88 WDL members (among four membership duration groups) and 23 nonmember farmers. Milk production and herd size were higher for greater-thanthree-year members compared to nonmembers and one-to-three-year members. The proportion of households with an income from dairy of greater than 5,000 ksh/month (ranging from 0 to 40 percent), food security (ranging from 4 to 30 percent), and number of improved household characteristics 
(ranging from 1.7 to 3.3), were positively associated with longer membership duration. While the crosssectional design does not allow attribution of causality, results suggested that WDL membership strengthened the livelihood assets of women farmers, particularly after three years, and that positive outcomes were sustained with longer membership duration. Anecdotally, women indicated that WDL's role in women's control of dairy income, regular payments, and food and services on credit, were important. WDL is a model to strengthen sustainable livelihoods through relevant gendered training, supports, and market access for agricultural products. Research to understand the optimal asset mix to benefit from dairy groups as well as factors limiting percow milk production is needed to guide future interventions and enhance the role of dairy farming for sustainable livelihoods.

\section{Keywords}

capacity building, cross-sectional survey, family welfare, food security, sustainability

\section{Introduction}

Kenya is a developing country of approximately 40 million people, with roughly 80 percent living in rural areas. Nearly one-half the population is poor (unable to meet their daily nutritional requirements) and the majority of the poor live in rural areas (IFAD, 2009). The climate is varied, with 20 percent of the land being conducive to agriculture, particularly in the Central and Rift Valley provinces. These provinces are characterized by bimodal rains, typically occurring in October and March, that support agriculture. Smallholder farmers raise animals and grow staple foods (maize and beans) and other crops on small parcels of land, usually less than 5 acres (2 hectares). Most smallholder households in sub-Saharan Africa rely on agriculture for a significant portion of their income; however, productivity is typically low. Enhancing agricultural productivity of smallholder farmers is one strategy for reducing food insecurity and rural poverty (Matshe, 2009).

Dairy farming potentially offers smallholder farmers higher returns on land and labor than crops such as coffee or tea, as well as the expecta- tion of regular income (Delgado, 1999). In Kenya, as with Tunisia and other countries, the demand for milk and milk products is strong and growing (Ben Salem \& Khemeri, 2008; Thorpe, Muriuki, Omore, Owango, \& Staal, 2000). Dairy-related technical training and improved livestock breeding have improved milk production and farm income in Kenya (Kisusu, 2000; Mullins, Wahome, Tsangari, \& Maarse, 1996), Tanzania (Bayer \& Kapunda, 2006), and Ethiopia (Ahmed, Jabbar, \& Ehui, 2000). Hildebrand (2008) concluded, however, that measures to improve productivity, such as improved animal health and breeding, remain underexploited in relation to improving food security and rural livelihoods. Factors limiting higher livestock productivity, including time constraints and limited access to extension services, affect women more than men, and may limit the participation and efficiency of women in livestock production (Kristjanson et al., 2010; Yisehak, 2008). In Kenya, women are the dominant dairy operators and, despite an increased workload with dairying, reported being better off due to income increases and stability (Mullins et al., 1996; Tangka, Ouma, \& Staal, 1999). In contrast, Ethiopian women generally were not responsible for cattlekeeping, and so intensification of dairying increased men's income with little impact on women's workload or income (Tangka, Emerson, \& Jabbar, 2002). Dairy intensification in a village in India increased the workload and stress of the women but without increased income (Sharma \& Vanjani, 1993). Women's control over income has been associated with purchases that provide a broader household benefit than purchases made by men. However, it is not uncommon for commercialization efforts to lead to more male control of activities and incomes (Huss-Ashmore, 1996; Kristjanson et al., 2010) in keeping with the traditional African view of cash income being part of the male domain (Gladwin, 2001).

Wakulima Dairy was established by a small group of community leaders in 1992, as a Self-Help Dairy Group, and governed by an elected board of representative farmers. Expansion of the activities and the number of members led to the incorporation of Wakulima Dairy Ltd. (WDL) in 2009. WDL remains governed by an elected board and has 
about 6,000 independent member farmers throughout the Mukurwe-ini district, Central province, Kenya. Its primary business is to buy raw milk from its members and transport and sell the milk to various markets. In addition, WDL broadly supports members by providing veterinary services, animal feeds, school fees, and staple household foods on credit. WDL has gained the trust of its member farmers through good overall governance and making monthly milk payments that provide members with a steady income. WDL has succeeded in providing farmers with stable markets for their milk by being a committed supplier of high-quality milk.

WDL has partnered with Farmers Helping Farmers (FHF), a Canadian NGO, since 1996, and with the Atlantic Veterinary College (AVC) since 2004, to strengthen the livelihoods of WDL's women farmers. Joint efforts were made to enhance dairy production through training and other supports and to retain women's control of dairy income. For three weeks each year, FHF volunteers and AVC faculty and students have assisted in practical training for farmers and efforts to improve the quality of animal health services. Four sequential projects with WDL were financed in part by the Canadian International Development Agency (CIDA). Kenyan staff, initially supported by project funds and then hired by WDL, continued the training throughout the year under the guidance of FHF and AVC. Women farmers were the focus of training, although not at the exclusion of men. Women were represented on the board of directors as a requirement of the FHF partnership.

Between 2004 and 2006, milk production and animal reproduction on WDL farms generally improved (VanLeeuwen et al., 2012). However, there is little published on broader sustainable livelihood (DFID, 2001) asset and outcome measures for women farmers belonging to community-based dairy organizations, nor on these measures associated with longer-term semicommercial dairying as a livelihood strategy.

To inform future projects and interventions, our study objectives were to determine relationships between dairy group membership and duration of membership, sustainable livelihood assets, household income, and food security.

\section{Materials and Methods}

\section{Study Site}

The 6,000 WDL member households located throughout Mukurwe-ini Division represent approximately 29 percent of the district's population (estimated at 84,000 inhabitants in 2009) (Kenya National Bureau of Statistics, 2009). Milk is collected in trucks along four rural routes and from members within walking distance of the milk plant. There are nonmember farmers living among the dairy group members.

\section{Study Design}

A cross-sectional survey of 88 WDL member households, evenly distributed over four membership-duration groups (one- to three-, four to six-, seven- to nine-, and 10-and-more years), and a fifth group of 23 nonmember households, was conducted in August 2009.

\section{Sampling}

A sample size of 20 households in each group was established to generate data with reasonable power, balanced with limited resources, to conduct the research. Ten percent oversampling per group was included in case of spoiled or missing data. There was no central list with duration status or contact information for the 6,000 WDL member farmers and no reasonable and efficient manner to establish such a database to allow us to draw a stratified random sample. As a result, study participants in the four membership-duration groups were identified using chain referral sampling. This method is used to access "hard to reach" populations, such as those in developing countries (Heckathorn, 2002; Penrod et al., 2003). With chain referral, the study sample is created by referrals made among people (members) who know others possessing the "character of research interest" (membershipduration) (Biernacki \& Waldorf, 1981). Eight WDL members were selected to initiate the referrals. These initiators represented a wide range of age, geographic distribution, and involvement within the dairy group. Each initiator referred farmer members who represented the four membershipduration groups. The research team contacted referred members to confirm membership dura- 
tion. This procedure was repeated until sufficient numbers of members in each membershipduration group were identified. Referred WDL members were asked to identify nonmembers to generate a nonmember list $(\mathrm{n}=50)$. The nonmember participants $(n=23)$ were randomly selected from this list. Directors and managers of WDL and teachers were excluded from the study to focus the research on households with farming as their primary livelihood strategy.

\section{Questionnaire Design}

The survey included open-ended and multiplechoice questions on household demographics and environment, farm characteristics, income, and household food security. Household environment questions, which examined housing (e.g., construction, repair, size), facilities (e.g., fuel, water, sanitation), and consumer assets (e.g., bicycle, radio), were modified from the Kenyan National Household Demographic and Health Survey (Central Bureau of Statistics [Kenya], Ministry of Health [Kenya], and ORC Macro, 2004). In order to develop a count index that represented household environment, housing and facilities were categorized as improved or not and a sum of improved home environment characteristics was computed for each household. For example, the number of buildings on the property and number of rooms in the main building was categorized as improved if the number was equal to or greater than the median number observed within the study. In addition, a vented cook house (i.e., with a chimney to exhaust wood smoke) and concrete or brick walls and floors were classified as improved. An improved latrine was one not shared with other families, as described in the Kenyan Demographic Survey (Kenyan National Bureau of Statistics [KNBS], 2010).

Primary and secondary household water sources were identified and included piped (to compound or neighbor), harvested rainwater, river or stream, public tap, and borehole (unprotected shallow well). The proportion of households using river or stream water as the primary or secondary source in both seasons was computed as an indicator of water access.

A measure of "household crowding" was computed from the number of daily household inhabitants divided by the number of rooms in the main building. Each household was categorized as above or below the median "crowding" for the study group.

Farm characteristics (e.g., acreage, herd size and age distribution, and milk production levels) were recorded. Monthly income (in categories) from milk, other farm product sales, and off-farm earned income were recorded. Milk income was based on the most recent full month of milk sales. Annual coffee income for 2008 was divided by 12 to estimate monthly coffee income. Midpoint values for each income stream were used to estimate household monthly income. Per-capita income was computed by dividing the monthly income estimate by the number of daily inhabitants. Women were asked who in the household controls the dairy income.

Household food insecurity (access) (HFIA) was measured using the validated "Household Food Insecurity Access Scale Version 3" (Coates, Swindale, \& Bilinsky, 2007). Briefly, this method captures and quantifies predictable experiences and responses of household food insecurity with reference to the previous four weeks. Nine questions address anxiety and the need to reduce food quality and/or quantity due to food shortages. Questions progress from experiences of mild to severe household food insecurity. For each question the frequency-of-occurrence is assessed as never, rare (one to two times), sometimes (three to 10 times), or often (more than 10 times). HFIA responses were tabulated as per Coates et al., (2007) and summarized by membership duration group to describe (1) the prevalence of households categorized as food secure, mildly food insecure, moderately food insecure, and severely food insecure; (2) the prevalence of households experiencing the conditions of "anxiety," "reduced quality," and "reduced quantity" of food; and (3) the overall HFIA score (as a continuous variable ranging from zero to 27). A "Household Hunger Score" (HHS) was computed for each household using the three most severe HFIA questions based on the HFIA cross-cultural validation study (Deitchler, Ballard, Swindale, \& Coates, 2010). The HFIA questions were culturally adapted to include 
local examples for prompts, as recommended (Coates et al., 2007).

Prior to use, the questionnaire was revised after review by WDL management and pre-testing on three households.

\section{Survey Administration}

Family, farm, and demographic questions were posed to the husband and wife, depending on availability, or only the man or woman in singleparent situations. The person responsible for food preparation in the home, usually the woman, was interviewed alone (when possible) for household food insecurity and income control questions. The interview was conducted in person, using a translator as needed.

\section{Data Handling and Analysis}

Data were coded, manually entered using Microsoft Excel 2007 (Microsoft Office, Microsoft Corp. 2007), and checked for accuracy. The distribution of continuous variables was assessed visually and transformed (i.e., natural logarithm) to achieve a normal distribution. The normal distribution of transformed variables was confirmed using the Shapiro-Wilks test. Standard chi-square or Fisher's exact (categorical variables), ANOVA (normally distributed continuous data), and Kruskall-Wallis (not-normally distributed continuous data) tests were used to determine associations among the five membership groups (nonmembers through 10and-more-year members), and among members and nonmembers for demographic, production, and livelihood outcomes. Statistical analyses were conducted using Stata 10. Significance was assessed at $\mathrm{p} \leq 0.05$.

Approval to conduct the study was obtained through FHF, WDL, and the University of Prince Edward Island Research Ethics Board prior to conducting the study. Signed consent was obtained from all participants after the nature of the study had been fully explained.

\section{Results}

\section{Human and Social Capital}

Men were the predominant heads-of-household (83 percent), while 10 percent of households were headed by widowed women. Overall, 83 percent of participants were married, which ranged from 65 percent in the seven- to nine-year group to 95 percent in the one- to three-year group. One participant was divorced and seven were single. Gender of household head and marital status were not associated with duration of membership.

As expected, the average age of WDL member mothers (range 21-73) and fathers (range 24-78) increased with longer WDL membership duration, although the age of newer member groups were similar (table 1). Comparing all-members to

Table 1. Household Demographics, by Dairy Group Membership Duration ${ }^{1}$

\begin{tabular}{|c|c|c|c|c|c|c|}
\hline & $\begin{array}{l}\text { Nonmembers } \\
\qquad(n=23)\end{array}$ & $\begin{array}{c}\text { Members } \\
1-3 \text { yrs. } \\
(n=23)\end{array}$ & $\begin{array}{c}\text { Members } \\
\text { 4-6 yrs. } \\
(n=22)\end{array}$ & $\begin{array}{c}\text { Members } \\
7-9 \text { yrs. } \\
(n=20)\end{array}$ & $\begin{array}{c}\text { Members } \\
10+\text { yrs. } \\
(n=23)\end{array}$ & $\begin{array}{c}\text { All- } \\
\text { Members } \\
(n=88)\end{array}$ \\
\hline Mother's age mean (SE) & 43.9 (3.0)a & 35.1 (2.2)ab & 34.4 (2.1)ab & $43.3(2.2) a b$ & 52.9 (2.1)ac & $41.5(1.3)$ \\
\hline Father's age mean (SE) & 52.3 (3.1)a & $40.7(2.4) b$ & 38.8 (2.5)b & 48.1. (3.8)ab & 62.5 (3.7)ac & $46.3(1.8)$ \\
\hline Household size ${ }^{2}$ mean (SE) & $5.1(0.4)$ & $4.0(0.3)$ & $4.3(0.3)$ & $4.3(0.4)$ & $3.8(0.4)$ & $4.1(0.2)^{*}$ \\
\hline \multicolumn{7}{|l|}{ Mother's education attended } \\
\hline$\%$ no formal \&primary & 90.9 & 81.2 & 69.6 & 50.0 & 63.6 & 66.7 \\
\hline$\%$ secondary & $9.1 \mathrm{a}$ & $18.2 \mathrm{ab}$ & $30.4 a b c$ & $50.0 b c$ & $36.4 \mathrm{bc}$ & $33.3 *$ \\
\hline \multicolumn{7}{|l|}{ Father's education attended } \\
\hline$\%$ no formal and primary & 81.8 & 70.0 & 63.7 & 25.0 & 80.0 & 62.4 \\
\hline \% secondary and higher & $18.2 a$ & $30.0 a$ & $36.4 a$ & $75.0 b$ & $20.0 a$ & $37.6 *$ \\
\hline
\end{tabular}

1 Values having the same letter within each row are not significantly different $(p<0.05)$

2 Usual residents who eat at the home $>5$ days per week

* All member and nonmember measures in the row are significantly different $(p \leq 0.05)$ 
nonmembers, the average mothers' and fathers' ages were not different. Average household size (daily occupants) was lower for all-members (4.1) compared to nonmembers (5.1) and ranged from one to 10 . Fewer nonmember mothers and fathers had secondary education compared to all-members. A significantly greater proportion of the seven- to nine-year group fathers had secondary education compared to other groups.

Fewer nonmember mothers (48 percent) were affiliated with a Women's Self-Help Group (Women's group) compared with all-member mothers (70.5 percent). There was no difference in the women's group member proportions among the groups of WDL members. Overall, 84 percent of women reported belonging to a church, with no difference among membership groups.

\section{Natural and Physical Capital}

Almost all (99 percent) participants owned their home and land. The number of household buildings (mean two, a main building and separate kitchen; range one to five) and the number of rooms in the main building (mean three, range one to eight) were not associated with membership duration group. All main buildings had roofs of corrugated steel and were constructed with brick
(45 percent) or wood plank/mud (55 percent) walls, with no membership group association. Duration of membership was positively associated with the proportion of households having a pit latrine at home, concrete or tile floors, and a vented cookhouse (table 2). All households cooked with firewood or charcoal, and the majority used light from kerosene lamps. Solar light was used by five households and five others used electricity for lighting. Household crowding ranged from 0.25 to 4.5 persons per room in the main building, with a median of 1.3. More nonmember households had higher-than-median crowding compared to allmembers. The number of improved household characteristics (range zero to six) was positively associated with duration of membership, specifically for households with seven or more years of WDL membership.

Fewer member households relied on river water in the dry season compared to nonmembers, and there was evidence of lower river-water reliance with longer membership duration (table 3). More all-members used piped water in the dry season compared with nonmembers. Rainwater, stored in small buckets and large cisterns, was the primary household water source in the wet season. Throughout both seasons, the proportion of

Table 2. Household Environment (\% of households) and Number of Improved Home Characteristics by Dairy Group Membership Duration ${ }^{1}$

\begin{tabular}{|c|c|c|c|c|c|c|}
\hline & $\begin{array}{l}\text { Nonmembers } \\
\quad(n=23)\end{array}$ & $\begin{array}{c}\text { Members } \\
1-3 \text { yrs. } \\
(n=23)\end{array}$ & $\begin{array}{c}\text { Members } \\
\text { 4-6 yrs. } \\
(n=22)\end{array}$ & $\begin{array}{c}\text { Members } \\
7-9 \text { yrs. } \\
(n=20)\end{array}$ & $\begin{array}{c}\text { Members } \\
10+\text { yrs. } \\
(n=23)\end{array}$ & $\begin{array}{c}\text { All- } \\
\text { Members } \\
(n=88)\end{array}$ \\
\hline \multicolumn{7}{|l|}{ Home construction } \\
\hline Concrete or tile floor & $4.4 a$ & $17.4 \mathrm{ab}$ & $18.2 \mathrm{ab}$ & $65.0 c$ & $52.2 c$ & $37.5^{*}$ \\
\hline Dirt floor & 95.6 & 82.9 & 81.8 & 35.0 & 47.8 & 62.5 \\
\hline \multicolumn{7}{|l|}{ Facilities and utilities } \\
\hline Pit latrine at home & $65.2 a$ & 73.9ab & $90.9 b c$ & $90.0 b c$ & 100.0c & $88.6 *$ \\
\hline Pit latrine at neighbour & 34.8 & 26.1 & 9.1 & 10.0 & 0.0 & 11.4 \\
\hline Vented cookhouse & $8.7 a$ & $21.7 a b$ & 18.2ab & $45.0 b$ & $39.1 b$ & $30.7 *$ \\
\hline \multicolumn{7}{|l|}{ Household crowding } \\
\hline$\%$ with $>1.3$ people/room & $78.3 a$ & $52.2 \mathrm{ab}$ & 63.6ab & $50.0 a b$ & $34.8 \mathrm{~b}$ & $50.0 *$ \\
\hline \multicolumn{7}{|c|}{ Number of improved characteristics } \\
\hline Mean (SE) & $1.7(0.2) \mathrm{a}$ & $2.1(0.2) \mathrm{a}$ & $2.2(0.3) a$ & $3.3(0.3) b$ & $3.3(0.3) b$ & $2.7(0.1)^{*}$ \\
\hline
\end{tabular}

${ }_{1}^{1}$ Values having the same letter within each row are not significantly different $(p<0.05)$

* All-members and nonmember measures in the row are significantly different $(p \leq 0.05)$ 
Table 3. Primary Water Source in the Dry and Wet season, by Dairy Group Membership Duration (\% of households) ${ }^{1}$

\begin{tabular}{|c|c|c|c|c|c|c|}
\hline Dry Season & $\begin{array}{c}\text { Nonmembers } \\
\quad(n=23)\end{array}$ & $\begin{array}{c}\text { Members } \\
1-3 \text { yrs. } \\
(n=23)\end{array}$ & $\begin{array}{c}\text { Members } \\
4-6 \text { yrs. } \\
(n=22)\end{array}$ & $\begin{array}{c}\text { Members } \\
7-9 \text { yrs. } \\
(n=20)\end{array}$ & $\begin{array}{c}\text { Members } \\
10+\text { yrs. } \\
(n=23)\end{array}$ & $\begin{array}{c}\text { All- } \\
\text { Members } \\
(n=88)\end{array}$ \\
\hline River or stream & $91.3 a$ & $69.6 a b$ & $50.0 b$ & $65.0 b$ & $52.2 b$ & $59.1^{*}$ \\
\hline Rainwater & 0 & 0 & 4.6 & 10.0 & 4.4 & 4.6 \\
\hline Piped $^{2}$ & $4.4 a$ & $21.7 a b$ & $27.3 b$ & 10.0ab & $43.5 b$ & $26.1 *$ \\
\hline Borehole, spring, other & 4.4 & 8.7 & 18.2 & 15.0 & 0 & 10.2 \\
\hline River as $1^{0}$ or $2^{0}$ & $91.3 a$ & $86.9 a b$ & $72.7 a b$ & $65.0 \mathrm{~b}$ & 69.6ab & 73.9 \\
\hline \multicolumn{7}{|l|}{ Wet Season } \\
\hline River or stream & 8.7 & 17.4 & 4.4 & 5.0 & 4.4 & 8.0 \\
\hline Rainwater & 91.3 & 69.6 & 78.3 & 80.0 & 65.2 & 72.7 \\
\hline Piped2 & 0 & 13.0 & 13.0 & 10.0 & 30.4 & 17.0 \\
\hline Borehole, spring, other & 0 & 0 & 4.4 & 5.0 & 0 & 2.3 \\
\hline River as $1^{0}$ or $2^{0}$ & $78.3 a$ & $47.8 b$ & $31.8 b$ & $35.0 b$ & $26.0 \mathrm{~b}$ & $35.2 *$ \\
\hline
\end{tabular}

${ }^{1}$ Values having the same letter within each row are not significantly different $(p<0.05)$

2 Water piped to compound, neighbour, public tap

* All-members and nonmember measures in the row are significantly different $(p \leq 0.05)$

households using river water as a primary or secondary source was lower for all-members compared with nonmembers, and was lower with longer duration of membership.

Nonmembers owned fewer consumer assets than all-members (table 4). Mobile phones and radios were the most predominant consumer asset. The proportion of all-member households with mobile phones was significantly higher than nonmembers'. Very few households owned a refrigerator, motorbike, or car/truck which reflected results for rural Kenya in the most recent national survey (KNBS, 2010).

Most households owned two acres $(0.8$ hectare) of land or less, with no difference among membership duration groups. More WDL members rented additional land than nonmembers (49 percent vs. 26 percent). Of these renters, most (88 percent) rented one acre ( 0.4 hectare) or less. The proportion of households dedicating their largest land area to napier grass (animal fodder) was higher with longer membership duration and there was a reverse trend for growing maize (figure 1). Members of the one- to three-year group did

Table 4. Consumer Assets Ownership, by Dairy Group Membership Duration (\% of households) ${ }^{1}$

\begin{tabular}{|c|c|c|c|c|c|c|c|}
\hline & $\begin{array}{l}\text { Nonmembers } \\
\quad(n=23)\end{array}$ & $\begin{array}{c}\text { Members } \\
1-3 \text { yrs. } \\
(n=23)\end{array}$ & $\begin{array}{c}\text { Members } \\
\text { 4-6 yrs. } \\
(n=22)\end{array}$ & $\begin{array}{l}\text { Members } \\
7-9 \text { yrs. } \\
(n=20)\end{array}$ & $\begin{array}{c}\text { Members } \\
10+\text { yrs. } \\
(n=23)\end{array}$ & $\begin{array}{c}\text { All- } \\
\text { Members } \\
(n=88)\end{array}$ & KNBS $^{3}$ \\
\hline \# of consumer assets ${ }^{2}$ & $1.7(0.2) a$ & $2.5(0.2) a b$ & $3.1(0.3) b$ & $2.6(0.3) a b$ & $2.3(0.2) a b$ & $2.6(0.1)^{*}$ & \\
\hline Radio & 74 & 91 & 91 & 80 & 77 & 85 & 71 \\
\hline Mobile phone & 65 & 96 & 96 & 100 & 86 & $94 *$ & 53 \\
\hline TV & 13 & 17 & 43 & 40 & 27 & 33 & 18 \\
\hline Bicycle & 13 & 26 & 44 & 20 & 18 & 27 & 34 \\
\hline Solar energy & 4 & 13 & 30 & 15 & 14 & 18 & 6 \\
\hline
\end{tabular}

${ }^{1}$ Values having the same letter within each row are not significantly different $(p<0.05)$

2 Mean number (SE) of the assets listed

3 Results for rural Kenya from Kenyan Demographic Household Survey 2008 for context (KNBS, 2010)

* All-members and nonmember measures in the row are significantly different $(p \leq 0.05)$ 
not follow the trend; many had their largest land area dedicated to growing coffee. Significantly more all-members (40 percent) than nonmembers $(9$ percent) dedicated the largest land area to napier grass production.

Significantly fewer allmembers ( 24 percent) dedicated their largest land area to maize production compared to nonmembers (61 percent). Some members (35 percent) and nonmembers (26 percent) dedicated their largest land area to coffee production.

\section{Dairy Farm Characteristics}

Women alone were responsible for dairy work on 51 percent of farms (range 31-70 percent across groups), and jointly with their husband on 45 percent of farms (range 13-70 percent across groups). Men alone were responsible for dairy work on 10-22 percent of farms across groups, and a hired hand was responsible for the dairy work in one household in the seven- to nine-year
Figure 1. Crop Occupying the Largest Farm Area, by Membership Group

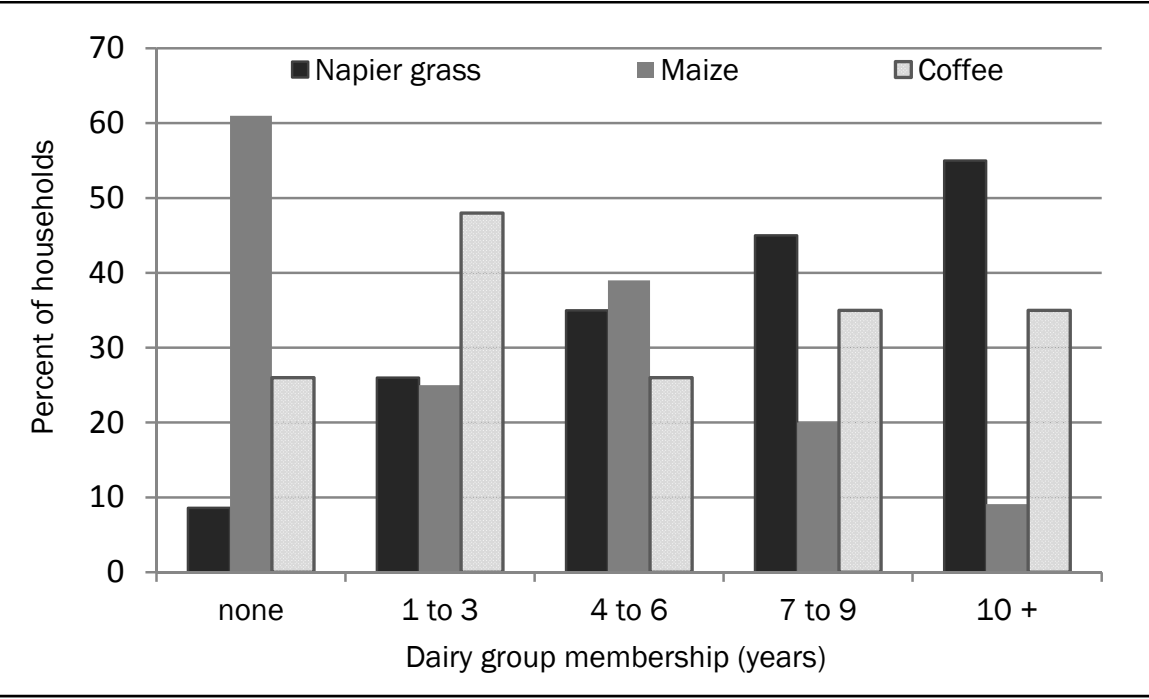

group and two in the 10-and-more-years group. No differences were observed among membership duration groups.

Herd size ranged from zero to six animals and the number of heifers from zero to four (table 5). Nonmembers with cattle had smaller herds and fewer lactating cows than all-members. No differences were seen in the number of heifers among the membership groups. Daily milk production per farm ranged from 2.2 to 99.2 pounds (one to $45 \mathrm{~kg}$ ), and per lactating cow

Table 5. Dairy Herd and Production Characteristics, by Dairy Group Membership Duration ${ }^{1}$

\begin{tabular}{|c|c|c|c|c|c|c|}
\hline & $\begin{array}{c}\text { Nonmembers } \\
(n=23)\end{array}$ & $\begin{array}{c}\text { Members } \\
1-3 \text { yrs. } \\
(n=23)\end{array}$ & $\begin{array}{c}\text { Members } \\
4-6 \text { yrs. } \\
(n=22)\end{array}$ & $\begin{array}{c}\text { Members } \\
7-9 \text { yrs. } \\
(n=20)\end{array}$ & $\begin{array}{c}\text { Members } \\
10+\text { yrs. } \\
(n=23)\end{array}$ & $\begin{array}{c}\text { All- } \\
\text { Members } \\
(n=88)\end{array}$ \\
\hline Herd size (all farms) & $0.7(0.2)$ & $1.8(0.2)$ & $2.5(0.2)$ & $2.2(0.3)$ & $2.3(0.3)$ & $2.2(0.1)^{*}$ \\
\hline Herd size $\llbracket$ & $1.3(0.1) a$ & $1.8(0.2) a b$ & $2.5(0.2) c$ & $2.2(0.3) \mathrm{bc}$ & $2.4(0.3) \mathrm{bc}$ & $2.2(0.1)^{*}$ \\
\hline \# lactating cows" & $0.3(0.1)$ & $1.0(0.1)$ & $1.2(0.2)$ & $0.9(0.2)$ & $1.0(0.2)$ & $1.0(0.1)^{\star}$ \\
\hline \# heifers" & $0.5(0.1)$ & $0.4(0.2)$ & $0.8(0.1)$ & $0.7(0.2)$ & $0.9(0.2)$ & $0.7(0.1)$ \\
\hline Kg milk produced/day§ & 3.1 (1.3)a & 6.4 (1.0)ab & $15.1(3.5) b$ & $11.5(1.9) \mathrm{b}$ & $11.3(1.8) \mathrm{b}$ & $10.3(1.1)^{*}$ \\
\hline Kg milk produced/cow/day§ & 3.1 (1.3)a & $5.5(0.6) a b$ & $7.7(1.2) \mathrm{b}$ & $8.9(1.0) b$ & $8.6(1.3) b$ & $7.5(0.5)^{*}$ \\
\hline$\%$ milk sold/day§ & $24.4(16.4)$ & $66.5(5.4)$ & $73.0(6.5)$ & $76.7(2.8)$ & $75.2(3.4)$ & $72.3(2.5)^{*}$ \\
\hline Kg home milk/capita/day! & $0.3(0.11)$ & $0.5(0.1)$ & $0.6(0.1)$ & $0.6(0.1)$ & $0.6(0.1)$ & $0.6(0.0)$ \\
\hline
\end{tabular}

${ }_{1}^{1}$ Data are expressed as mean (SE) for consistency; values having the same letter within each row are not significantly different $(p<0.05)$

* All-member vs. nonmember measures in the row are significantly different $(p \leq 0.05)$

"I Includes only farms with cattle ( $n=13$ for nonmembers, $n=22$ for $10+$ members)

$\S$ Milk production data from farms with lactating cows ( $n=4$ for nonmembers; $n=20,15,13,17$ for $1-3,4-6,7-9,10+$ years,

respectively) 
Table 6. Monthly Income and Income Control by Dairy Group Membership Duration ${ }^{1}$

\begin{tabular}{|c|c|c|c|c|c|c|}
\hline & $\begin{array}{c}\text { Nonmembers } \\
\left(\mathrm{n}^{2}\right)\end{array}$ & $\begin{array}{c}\text { Members } \\
1-3 \text { yrs. } \\
(n=23)\end{array}$ & $\begin{array}{c}\text { Members } \\
4-6 \text { yrs. } \\
(n=22)\end{array}$ & $\begin{array}{c}\text { Members } \\
7-9 \text { yrs. } \\
(n=20)\end{array}$ & $\begin{array}{c}\text { Members } \\
10+\text { yrs. } \\
(n=23)\end{array}$ & $\begin{array}{c}\text { All- } \\
\text { Members } \\
(n=88)\end{array}$ \\
\hline Total per capita income (Ksh) ${ }^{3}$ & $\begin{array}{c}278 \\
(58,729)\end{array}$ & $\begin{array}{c}1562 \\
(1250,2770)\end{array}$ & $\begin{array}{c}2500 \\
(1000,2667)\end{array}$ & $\begin{array}{c}2867 \\
(1429,4500)\end{array}$ & $\begin{array}{c}2094 \\
(1111,2850)\end{array}$ & $\begin{array}{c}2010 * \\
(1150,3055)\end{array}$ \\
\hline Non-dairy per capita income (Ksh) & $\begin{array}{c}278 \mathrm{a} \\
(58,625)\end{array}$ & $\begin{array}{c}847 a b \\
(417,1750)\end{array}$ & $\begin{array}{c}833 a b \\
(200,2006)\end{array}$ & $\begin{array}{c}1619 \mathrm{~b} \\
(1060,3423)\end{array}$ & $\begin{array}{c}570 a b \\
(361,1458)\end{array}$ & $\begin{array}{c}917 * \\
(416,1979)\end{array}$ \\
\hline \multicolumn{7}{|l|}{ Monthly dairy income } \\
\hline$\%$ of farms earning $0-5000 \mathrm{Ksh}$ & 100 & 91 & 64 & 60 & 68 & $71 *$ \\
\hline$\%$ of farms earning $>5000 \mathrm{Ksh}$ & $\mathrm{Oa}$ & $9 a b$ & $36 c$ & $40 c$ & $32 \mathrm{bc}$ & 29 \\
\hline \multicolumn{7}{|l|}{ Dairy income control } \\
\hline $\begin{array}{l}\% \text { of farms women sole or joint } \\
\text { control control (man\&woman) }\end{array}$ & $\mathrm{Na}$ & 78 & 77 & 80 & 78 & 79 \\
\hline
\end{tabular}

1 Values having the same letter within each row are not significantly different $(p<0.05)$

$2 \mathrm{n}=13$ for nonmembers' total and nondairy incomes; $n=2$ for nonmembers' dairy incomes

${ }^{3}$ Median per capita incomes with $25^{\text {th }}$ and $75^{\text {th }}$ percentiles; the Kenyan shilling to U.S. dollar exchange rate was approximately 80 at the time of the study (OANDA Historical Exchange Rates, http://www.oanda.com/currency/historical-rates/)

* Member and nonmember measures in the row are significantly different $(p \leq 0.05)$.

ranged from 2.2 to 50.7 pounds (one to $23 \mathrm{~kg}$ ). These production measures were higher for allmembers compared with nonmembers and specifically for longer-term (greater than threeyear) members. Short-term (one- to three-year) members had intermediate total and per-cow daily milk production. The proportion of milk sold ranged from zero to 96 percent, and was significantly higher for all-members compared with nonmembers, with no difference among WDL member groups. Milk retained for home use, from households with lactating cows, ranged from 0.3 to $3.3 \mathrm{lbs}$. / capita ( 0.12 to $1.5 \mathrm{~kg} /$ capita). One twomember household with four heifer calves retained $8.8 \mathrm{lbs}$. (4kg) of milk for household use. It was expected that some of the home-use milk was for feeding calves. On average all-members retained twice the per-capita milk compared with the nonmembers $(\mathrm{n}=4)$ with lactating cows. This difference was not statistically significant, but represents a potentially nutritionally significant trend depending on intrahousehold allocation.

\section{Household Income and Income Control}

Household monthly income, from milk and coffee sales and casual and full-time jobs, ranged from zero to 27,000 Kenyan shillings (Ksh) (USD0 to USD337.50). Per-capita total and nondairy income was higher for all-members compared to nonmembers (table 6). Income figures for nonmembers were of limited value, as many $(n=13)$ nonmembers did not disclose coffee

Table 7. Degree of Household Food Insecurity by Dairy Group Membership Duration (\% of households) ${ }^{1}$

\begin{tabular}{lcccccc}
\hline & $\begin{array}{c}\text { Nonmembers } \\
(\mathrm{n}=23)\end{array}$ & $\begin{array}{c}\text { Members } \\
\mathbf{1 - 3} \text { yrs. } \\
(\mathrm{n}=23)\end{array}$ & $\begin{array}{c}\text { Members } \\
\mathbf{4 - 6} \text { yrs. } \\
(\mathrm{n}=22)\end{array}$ & $\begin{array}{c}\text { Members } \\
\mathbf{7 - 9} \text { yrs. } \\
(\mathrm{n}=20)\end{array}$ & $\begin{array}{c}\text { Members } \\
\mathbf{1 0 +} \text { yrs. } \\
(\mathrm{n}=23)\end{array}$ & $\begin{array}{c}\text { All- } \\
\text { Members } \\
(\mathrm{n}=88)\end{array}$ \\
\hline Secure & $4.4 \mathrm{a}$ & $17.4 \mathrm{ab}$ & $27.3 \mathrm{~b}$ & $25.0 \mathrm{ab}$ & $30.4 \mathrm{~b}$ & $25.0 *$ \\
Mildly insecure & 8.7 & 0 & 13.6 & 20.0 & 26.1 & 14.8 \\
Moderately insecure & 26.1 & 47.8 & 22.7 & 30.0 & 17.4 & 29.6 \\
Severely insecure & $60.9 \mathrm{a}$ & $34.8 \mathrm{ab}$ & $36.4 \mathrm{ab}$ & $25.0 \mathrm{~b}$ & $26.9 \mathrm{~b}$ & $30.7 *$ \\
\hline
\end{tabular}

1 Values having the same letter within each row are not significantly different $(p<0.05)$

* All-members and nonmember measures in the row are significantly different $(p \leq 0.05)$ 
Table 8. Prevalence of Food Insecurity in Three Domains, by Dairy Group Membership Duration (\% of households) ${ }^{1}$

\begin{tabular}{|c|c|c|c|c|c|c|}
\hline Domain & $\begin{array}{l}\text { Nonmembers } \\
(\mathrm{n}=23)\end{array}$ & $\begin{array}{c}\text { Members } \\
1-3 \text { yrs. } \\
(n=23)\end{array}$ & $\begin{array}{c}\text { Members } \\
\text { 4-6 yrs. } \\
(n=22)\end{array}$ & $\begin{array}{l}\text { Members } \\
7-9 \text { yrs. } \\
(n=20)\end{array}$ & $\begin{array}{c}\text { Members } \\
10+\text { yrs. } \\
(n=23)\end{array}$ & $\begin{array}{c}\text { All- } \\
\text { Members } \\
(n=88)\end{array}$ \\
\hline Anxiety ${ }^{2}$ & 69.6 & 56.5 & 59.1 & 60.0 & 47.8 & 55.7 \\
\hline Reduced quality 3 & $95.6 a$ & $82.6 a b$ & $68.2 b$ & $70.0 \mathrm{~b}$ & $60.9 b$ & 70.4 \\
\hline Reduced intake 4 & $73.9 a$ & $56.5 a b$ & $40.9 b$ & $35.0 b$ & $34.8 b$ & 42.1 \\
\hline
\end{tabular}

${ }_{1}$ Values having the same letter within each row are not significantly different $(p<0.05)$

${ }^{2}$ Anxiety: having feelings of uncertainty or anxiety over not having enough food

${ }^{3}$ Reduced quality: not eating preferred foods, eating a limited variety of foods, or eating less preferred foods

${ }_{4}^{4}$ Reduced intake: eating smaller or fewer meals, having no food stores in the home, going to sleep hungry, or not eating for a full day

income. A greater proportion of households with more than three years of membership had high (more than $5000 \mathrm{Ksh} /$ month or USD62.50) dairy income compared with one- to three-year members and nonmembers. Almost 80 percent of allmember women reported sole or joint control of dairy income. The two nonmembers reporting milk sales were not asked about who controlled dairy income because they did not sell milk to WDL.

\section{Household Food Security}

Among WDL members, 25 percent were food

\section{Figure 2. Household Food Insecurity Score (Median, Interquartile Range, and Range) by Dairy Group Membership Duration}

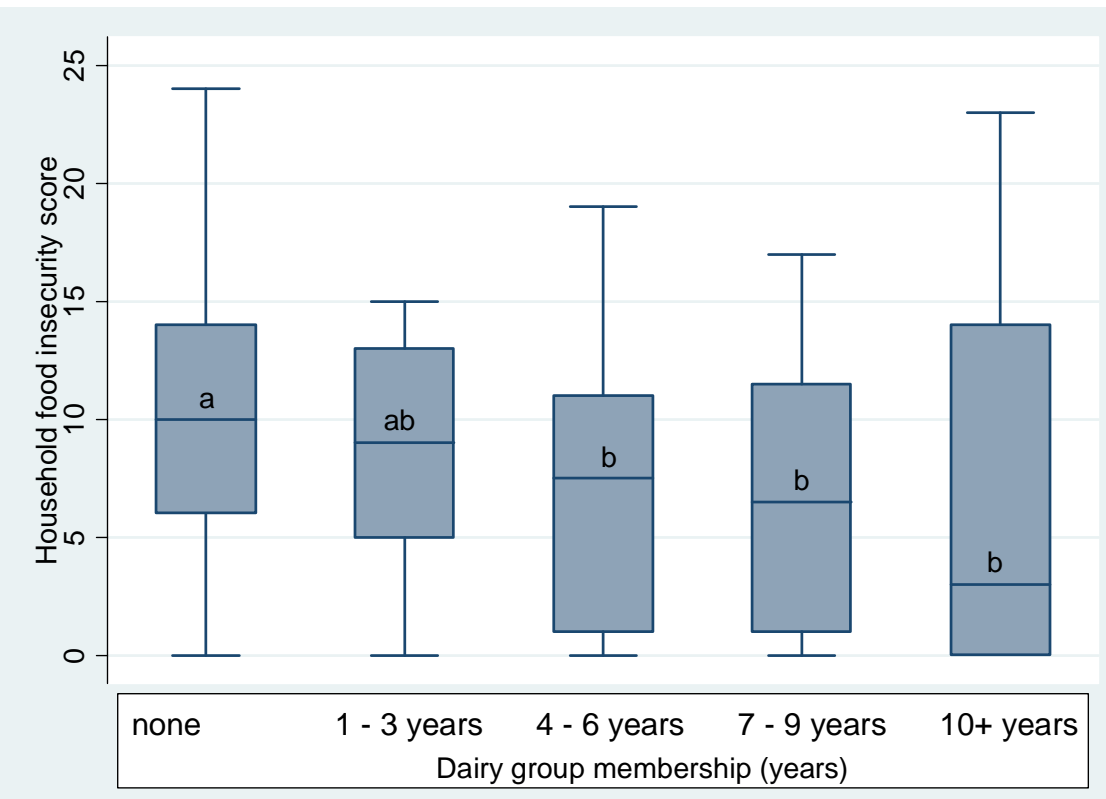

a Boxes with different letters have significantly different medians $(p \leq 0.05)$ secure. A positive trend in the proportion of households classified as food secure by duration of membership was observed (table 7). An opposite trend was observed for the proportion of severely food insecure households, which was lower as membership duration lengthened. More allmembers were categorized as food secure than nonmembers, particularly among members with more than three years of membership.

The proportion of households expressing anxiety over food security (the least severe form of food insecurity) was not different between groups

(table 8). Dairy group membership for more than three years was associated with fewer households that needed to reduce quality and quantity of foods consumed in the previous month compared with nonmembers. The proportion of households reporting reduced food quality or quantity among the four- to six-, seven- to nine-, and greater-than- 10 year membership groups was not significantly different.

HFIA scores ranged from zero to 24 , with a maximum possible score of 27 (figure 2). Longer-term (greater than three-year) dairy group members had better household food 
security (lower HFIA score) compared with nonmembers $(p<0.10)$. Nonmember and one- to three-year member HFIA scores were not significantly different. HFIA scores for the three membership groups with more than three years of membership were also not significantly different, although the median HFIA score exhibited a linear trend $(p<0.01)$ toward lower food insecurity with longer membership duration. Household Hunger Scores were not associated with duration of membership.

\section{Discussion}

This study clearly demonstrated that belonging to the WDL dairy group in Kenya and the duration of membership were positively associated with women's livelihood assets and outcomes. Strengthened human, financial, and physical capital likely contributed to the increased resilience, capabilities and positive livelihood outcomes seen in WDL members. Rural agro-industries, such as WDL, are recognized as important links between farmers and the market (Moron, 2006) and may help address the many challenges to smallholder farmers entering "semicommercial" agriculture, which include unreliable markets for household food and limited transportation, agricultural support services, and market access for the surplus agricultural products (Bebe, 2003; Jaleta, Gebremedhin \& Hoekstra, 2009).

\section{Human and Social Capital}

The age of the household adults increased with membership duration, as expected. However, the mean age of all-members compared with nonmembers was not different, and therefore comparisons between these two groups, with similar time to learn, farm, and accumulate assets, are valid.

WDL member men and women had higher formal education levels and more member women participated in womens' groups. Higher education can increase human capital and positively impact capabilities, and may reflect higher overall livelihood assets that enable the investment in dairying; both scenarios making semicommercial farming more achievable. Women's groups often provide microfinance to members, as well as learning opportunities, social security, and assistance in times of crisis (Cubbins, 1991). Members of women's groups may be better positioned to become WDL members and implement dairy production enhancements. However, attributing motivations and enabling factors for joining WDL was beyond the scope of this research.

WDL member women reported full or joint dairy income control in almost 80 percent of households and within the context of longer-term semicommercial production. Tangka et al., (1999) found that 76 percent of Kenyan women in market-oriented smallholder dairying had some or full control of dairy income, although the traditional African view is that cash income is part of the male domain (Gladwin, 2001). HussAshmore (1996) found that men controlled more of the dairy income in larger, more commercial farm households in Uasin Gishu District, Kenya. In Malawi and Uganda, men controlled highrevenue-generating commodities sold in formal markets (Njuki, Kaaira, Chamunorwa, \& Chiuri, 2011). From this cross-sectional study we are not able to derive whether the efforts of the WDLFHF partnership were a factor in the sustained income control. However, it is generally accepted that income in women's hands provides more household benefit than income in men's hands (Mullins, et al., 1996), which may help explain strengthened livelihood assets and more household food security observed for WDL member households.

\section{Natural Capital}

Land access is very important to those who derive all or part of their livelihood from agricultural production. WDL members' ability to access additional rented land may be associated with higher income from higher milk production. As a result, member households may have greater capacity for sustainable livelihoods compared to nonmembers.

Land use differences between members and nonmembers (proportion of land used for napier grass as animal fodder versus maize production) are representative of the change typically seen when farmers transition from subsistence to 
semicommercial agriculture (Jaleta, et al., 2009). The positive association of land use for napier grass and membership duration suggests that this land use shift occurred gradually and may represent greater commitment to dairy farming as a livelihood strategy over time. This difference also suggests more sustainable land use. Perennial napier grass has a broad leafy canopy and extensive root system that potentiallyreduce the rate of soil erosion compared with maize and coffee, which leave erodible soil exposed to water and wind. In addition, WDL members, who have relatively larger herds after the first three years of membership, have increased manure available from their own livestock, which, when used on crop and pasture plots, can increase crop yields and improve soil quality (Lwelamira, Binamungu, \& and Njau, 2010).

The one- to three-year membership group was the exception to the observed land use trend. More farmers allotted their largest land area to coffee production. Higher world coffee prices and Kenyan government-initiated coffee market reforms initiated in 2003 (PKF Consulting Ltd. \& International Research Network, 2005) may have impacted land use decisions by these farmers.

\section{Physical Capital}

Housing characteristics and asset ownership, rather than measures of current welfare or poverty, are commonly used to measure economic trends in developing countries (Wamani, Tylleskør, Åstrøm, Tumwine, \& Peterson, 2004). In general, regular income is used for food and other daily expenses, whereas income received infrequently and in large amounts tends to be spent on large items (Morris, Carletto, Hoddinott, \& Christiaensen, 2000). Some Tanzanian households belonging to a wellmanaged community dairy group were able to improve their homes after three to five years of membership (Bayer \& Kapunda, 2006). It is possible that improved household characteristics (latrine, concrete floor, vented cookhouse) and water access may have pre-existed the membership and enabled households to participate in intensified dairying. The differences observed with longer WDL membership duration suggest, however, that these improvements resulted from longer-term, stable dairy income. Although dairy income is received regularly, "building a house" was cited as one of the benefits of WDL membership (Walton, 2012). Improved sources and access (piped and sufficient rainwater) to water may similarly reflect the income benefits of longer WDL membership through investment in community water projects or the purchase of rainwater storage cisterns that are adequate to meet household needs during the wet season. The cross-sectional nature of the study does not, however, allow us to draw conclusions of causal relationships.

The differences observed in household characteristics for those with longer membership duration, suggest the potential for improved health and well-being and, consequently, strengthened human capital, through reduced risk of disease (due to having their own latrine, being less crowded, and having improved water sources) and respiratory problems and eye irritation (due to having a vented cookhouse) as well as, for women and children, a reduced burden of carrying river water.

\section{Farm Production and Financial Capital}

WDL farmer training included best practices for breeding, raising, and maintaining healthy, productive animals. WDL also provided veterinary and artificial insemination services on credit to members. These activities are recognized capacitybuilding and supports needed to reduce reproductive losses and lead to sustained long-term benefits (Bebe, 2003; Walingo, 2006). Herd size, milk production (total and per cow), and dairy income were positively associated with WDL membership duration, particularly after three years of membership. Herd size for nonmembers reflected the median herd size of 1.3 animals reported for smallholders in the Kenyan highlands (Bebe, 2003). Increased milk production and incomes of smallholder farmers resulting from the use of cross-bred cows and better livestock management through farmer training, has been reported after two to four years in Ethiopia (Ahmed et al., 2000) and after three years in Kenya (Walingo, 2009). Sustained higher milk production with longer WDL membership may be attributed to the ability of WDL to market and pay for milk and to women retaining control of dairy income. 
Income control may enable women to fulfill their traditional role as food providers (Gladwin, 2001), while devoting their limited resources to dairying as a cash crop. Increased milk production in Tunisia due to similar interventions was not sustained beyond the intervention period, and this was attributed to the lack of common interest groups and leadership development (Ben Salem, 2008), although gender was not addressed in the intervention nor the evaluation. Nonmembers in our study had low milk production despite the potential to learn from WDL members in their communities. This may reflect the importance of belonging to a supportive group for training and implementation of enhanced agricultural practices.

In our study, per-cow milk production varied widely, which may be due to the low number of lactating cows in the study, and the fact that cow age, stage of lactation, and other influential factors were not taken into account. These factors limit interpretation of relationships between duration of WDL membership with milk production levels. The average per-cow milk production was not different for members after three years of membership and was low relative to the maximum observed. With generally low incomes and only 25 percent of households classified as food secure, there is a need to examine the role that higher milk production may play in addressing these issues.

The low number of lactating animals in nonmember farms seemed to contrast with the relatively high number of heifers, as a young heifer can often indicate the presence of a lactating cow. This may be explained by nonmembers purchasing heifers or by low reproductive rates in the Kenyan highlands (Bebe, 2003), leading to older heifers and nonlactating cows. Other WDL intervention supports (e.g., a cow loan program) may explain the higher numbers of dairy animals for WDL members.

The seven- to nine-year member group had a larger proportion of households with high percapita dairy and other income. A larger proportion of this group had some secondary education. As previously discussed, education can increase human capital and capabilities and make semicommercial farming more achievable. The cross-sectional nature of the study, however, does not allow us to draw conclusions of causal relationships.

\section{Household Food Security}

The measurement of household food security as a complex phenomenon that includes psychological stress, coping mechanisms, and hunger, is evolving (Coates, et al., 2006). Previously reported smallholder dairy development projects used proxy measures of food security (farm productivity, income, milk and food consumption, and caloric intake) (Ahmed et al., 2000; Huss-Ashmore, 1996; Lwelamira et al., 2010; Nicholson, Thornton, \& Muinga, 2004). Developments in the measurement of household food security led us to reveal the relationship between WDL membership and membership duration and (1) the severity of household food insecurity, and (2) the prevalence of households with anxiety about food access and with the need to reduce food quality and quantity due to limited resources.

August 2009, the time of the survey, was a lean period just prior to the maize harvest. In addition, there was a recent drought resulting in low maize yields; limited national food availability; and soaring world food prices (Wodon, 2010; World Vision, 2012). Anxiety about food access was widespread and not different between members and nonmembers, as expected when rains fail to come (Hadley \& Patil, 2008). However, fewer member households, especially beyond three years of membership, reduced food quality and quantity, and consequently, fewer members were categorized as severely food insecure. The one- to three-year member households were intermediate in their degree of food insecurity and need for food quality and quantity reduction. This observation corresponds with their intermediate milk production and milk income, and further supports the argument that the benefits of WDL membership increase with longer duration. This group may have less access to staple food on credit from WDL compared to longer-term members due to lower milk sales to the dairy, further limiting household food security.

The HFIA score is considered a sensitive indicator of program impacts (Coates et al., 2006). In our study, a linear decline of median HFIA 
score (representing improving food security) with membership duration occurred despite members devoting more land to animal feed production, a recent drought, and high food prices. This situation indicates greater resilience and more sustainable livelihoods and likely reflects the benefits of longterm WDL membership. As well, women retaining control over dairy income is likely associated with these food security results. Dairy income was more often used to buy food on dairy farms where gender relations were addressed compared with farms where women accrued less of the income in proportion to their labor (Mullins et al., 1996).

There was, however, a great deal of variation of the HFIA scores within the membership groups, reflecting the many intrahousehold variables and events beyond the scope of this research that can affect household food security.

Members retained twice the milk (per capita) compared to nonmembers $(1.3 \mathrm{lbs}$. capita/d or 0.6 $\mathrm{kg} / \mathrm{capita} / \mathrm{d}$ vs. $0.7 \mathrm{lbs}$ / capita/d or 0.3 $\mathrm{kg} / \mathrm{capita} / \mathrm{d}$, respectively, $p=0.10$ ), even with greater commercialization as reflected by the proportion of milk sold by member households. The lack of statistical differences was due, in part, to low statistical power with a small number of nonmembers owning lactating cows $(n=4)$. In contrast, in an Indian village where a milkmarketing cooperative operated, households consumed less milk compared to households in villages where cooperatives did not operate (Alderman, 1994). The per-capita milk retained by nonmembers (0.27 qt. (US)/ capita/d or 0.26 $\mathrm{L} /$ capita/d) was similar to the milk consumption for Kenyan highland farm adults without cattle or with local cattle breeds (0.34 qt.(US)./capita/d, or $0.32 \mathrm{~L} /$ capita/d) (Nicholson et al., 2003). Higher average household milk consumption was found in dairy intensification programs in central Kenya (0.95 qt.(US) / capita/d or $0.9 \mathrm{~L} /$ capita/d) (Nicholson et al., 2003). ( $\mathrm{Kg}$ and liters are used synonymously here for milk measurement.) In our study, the per-capita milk retained was less than that reported by Nicholson et al. (2003), but was more than the WDL farmer training that promoted "two cups" of milk daily for each household member (Walton, 2012).
By providing general support and its specific efforts to strengthen human capital, WDL likely contributed to higher milk production, leading to both greater income and improved household food security. We hypothesize that these positive outcomes enabled members to strengthen their financial, physical, and natural assets that positively influenced their well-being, vulnerability, and sustainable land use. Most importantly, these positive results appeared to be sustained and some increased, with longer WDL membership duration. "Intermediate" was used to describe the dairy production and livelihood asset and outcome measurements for one- to three-year members. Other studies found higher milk production, average per-capita milk consumption, and income from milk sales among farmers involved in dairying for at least three years (Lwelamira et al., 2010; Walingo, 2009). We assert that this early period is needed to enhance women's capacity and confidence to use their limited resources for enhanced milk production. Most African women consciously plant and tend subsistence crops before most cash crops in order fulfill their traditional role as food providers (Gladwin, 2001). We believe the provision of staple food and other goods and services on credit from WDL are important supports for women to adopt semicommercial dairying.

Limitations of the study include the crosssectional design, which limits causal statements of the effect of dairy group membership (or duration) on specific outcomes. Members had higher levels of education (men and women) and social capital (women's group membership) that may have enabled them to become WDL members and to adopt enhanced dairying practices. More members had access to additional (rented) farmland, which may further positively impact their livelihood outcomes, and which may, or may not, result from dairy income. Another limitation was the use of chain referral sampling and its potential for selection bias, where an unbiased random stratified sample is preferred. To minimize the potential for this bias, chain referral sampling was carefully conducted and monitored (such as by using eight WDL member chain initiators with wide geographical distribution, and encouraging all 
initiators to refer households from all membership strata). Many characteristics of WDL and its partnerships are specific to this context and may limit generalizability of our results. Finally, comparability of food security assessment to other situations is limited, as the tool was not fully crossculturally validated (Deitchler et al., 2010).

\section{Conclusions}

Our results support the statement that WDL membership status and duration are positively associated with income and food security and with strengthened livelihood assets that potentially impact additional outcomes (well-being, vulnerability, and more sustainable land use). We believe these results are strongly linked to the fact that women were the traditional dairy farmers and that efforts were made throughout the WDL-NGO partnership to train women farmers and keep dairy income in their control. This study illustrates a positive example for strengthening sustainable livelihoods of smallholder women dairy farmers; a strong and long-term NGO partnership with resources invested by all partners; a well-governed community-based organization; and gender mainstreaming through women in decision-making, access to training, income control, and credit-based supports.

Movement to commercial production has the potential to paradoxically place a household at risk of food insecurity. Our results showed a positive association of per-capita income with WDL membership and of the prevalence of food secure households with membership duration. However, incomes were generally low and the majority of households were not food secure. Milk production (average per cow) was relatively low, even after the three-year adaptation period. There is a need to identify and address barriers for households to join dairy groups and factors limiting the rate of adaptation and the extent to which enhanced methods for milk production are adopted. Further, this knowledge will help guide interventions to increase income and household food security and to maximize the potential of dairy farming for sustainable livelihoods.

We recognize the limitation of the crosssectional study design, which does not allow statements on direct causal effects of membership duration to be made. Further research using a longitudinal study design and a randomized sample would help fulfill the criteria for causality needed to confirm these hypothesized "impacts" of dairy group membership.

\section{Acknowledgements}

The authors would like to recognize Veterinarians Without Borders and the XXIII World Veterinary Congress Foundation for financial support for data collection. The cooperation of Farmers Helping Farmers and Wakulima Dairy Ltd. and the openness and honesty of member and nonmember farmers is truly appreciated. The efforts of Regina Gitau, Samwel Mbugua, Lisa Wolff, and Ruth Wanjiro were paramount for locating the many rural households, translating, and patiently and persistently conducting the survey.

\section{References}

Ahmed, M. M., Jabbar, M., \& Ehui, S. (2000). Household-level economic and nutritional impacts of market-oriented dairy production in the Ethiopian highlands. Food and Nutrition Bulletin, 21(4), 460-465.

Alderman, H. (1994). Why should it matter what commodity is the source of agricultural profits? Dairy development in India. In J. Von Braun \& E. Kennedy (Eds.), Agricultural commercialization, economic development, and nutrition (pp. 239-251). Baltimore, Maryland: Johns Hopkins University Press. Retrieved from http://www.ifpri.org/sites/default/ files/publications/vonbraun94.pdf

Bayer, W., \& Kapunda, L. B. (2006, October). Dairy cattle for poverty alleviation in southern Tanzania. Conference on International Agricultural Research for Development, at the University of Bonn. Retrieved from http://www.tropentag.de/2006/abstracts/ full/415.pdf

Bebe, B. O. (2003). Herd dynamics of smallholder dairy in the Kenyan higblands (Doctoral dissertation), Wageningen University, The Netherlands. Retrieved from http://edepot.wur.nl/121373

Ben Salem, M., \& Khemiri, H. (2008). The impact of agricultural projects on cows' productivity, farmers' revenue and rural development in Tunisia. Livestock Research for Rural Development, 20(5). Retrieved from http://www.lrrd.org/lrrd20/5/sale20070.htm 
Biernacki, P., \& Waldorf, D. (1981). Snowball sampling: Problems and techniques of chain referral sampling. Sociological Methods and Research 10(2), 141-163.

Central Bureau of Statistics (CBS) [Kenya], Ministry of Health (MOH) [Kenya], \& ORC Macro. (2004). Kenya demographic and health survey 2003. Calverton, Maryland: CBS, MOH and ORC Macro. Retrieved from http://www.measuredhs.com/publications/ publication-FR151-DHS-Final-Reports.cfm

Coates, J., Swindale, A., \& Bilinsky, P. (2007). Household food insecurity access scale (HFLAS) for measurement of bousehold food access: Indicator guide (v. 3). Washington, D.C.: Food and Nutrition Technical Assistance Project, Academy for Educational Development.

Cubbins, L. A. (1991). Women, men, and the division of power: A study of gender stratification in Kenya. Social Forces, 69(4), 1063-1083. Retrieved from http://www.jstor.org/stable/2579302

Deitchler, D., Ballard, T., Swindale, A., \& Coates, J. (2010). V alidation of a measure of household hunger for cross-cultural use. Washington, D.C.: Food and Nutrition Technical Assistance II Project.

Delgado, C. L. (1999). Livestock to 2020: The next food revolution. (Food, agriculture, and the environment discussion paper 28). Washington, D.C.: International Food Policy Research Institute; Rome, Italy: Food and Agriculture Organization of the United Nations; Nairobi, Kenya: International Livestock Research Institute. Retrieved from the International Food Policy Research Institute website: http://www.ifpri.org/2020/dp/dp28.pdf

Department for International Development [DFID]. (2001). Sustainable livelihoods guidance sheets (DFID) London. Retrieved from http://www.eldis.org

Gladwin, C. H., Thomson, A. C., Peterson, J. S., \& Anderson, A. S. (2001). Addressing food security in Africa via multiple livelihood strategies of women farmers. Food Policy, 26(2), 177-207. http://dx.doi.org/10.1016/S0306-9192(00)00045-2

Hadley, C., \& Patil, C. L. (2008). Seasonal changes in household food insecurity and symptoms of anxiety and depression. American Journal of Physical Anthropology, 135(2), 225-232. http://dx.doi.org/10.1002/ajpa.20724

Heckathorn, D. D. (2002). Respondent-driven sampling II: Deriving valid population estimates from chainreferral samples of hidden populations. Social
Problems, 49(1), 11-34.

http://dx.doi.org/10.1525/sp.2002.49.1.11

Hildebrand, H. (2008). Small-scale farmers secure income for millions. Livestock production in developing and further developed countries. Neue Landwirtschaft, (9), 62-66. Retrieved from http://search.ebscohost.com/login.aspx?direct= true \&db $=$ lah\&AN $=20083318293 \&$ site $=$ ehost-live

Huss-Ashmore, R. (1996). Livestock, nutrition, and intrahousehold resource control in Uasin Gishu district, Kenya. Human Ecology, 24(2), 191-213. http://dx.doi.org/10.1007/BF02169126

Internationals Fund for Agricultural Development [IFAD]. (2009). Rural Poverty Portal: Rural poverty in Kenya. Retrieved from http://www.ruralpoverty portal.org/web/guest/country/home/tags/kenya

Jaleta, M., Gebremedhin, B., \& Hoekstra, D. (2009). Smallholder commercialization: Processes, determinants and impact (Discussion paper 18). Improving productivity and market success (IPMS) of Ethiopian farmers. Nairobi, Kenya: International Livestock Research Institute [ILRI].

Kenya National Bureau of Statistics, 2009. Population and housing census. Retrieved from https://opendata.go.ke/

Kenya National Bureau of Statistics [KNBS] \& ICF Macro. (2010). Kenya demographic and health survey 2008-09. Calverton, Maryland: KNBS and ICF Macro. Retrieved from http://www.measuredhs. com/pubs/pdf/FR229/FR229.pdf

Kisusu, R. W., Mdoe, N. S. Y., Turuka, F. M., \& Mlambiti, M. E. (2000). Contribution of smallholder dairy production to food security, household income and poverty alleviation: The case of Mvumi dairy development project, Dodoma. Tanzanian Veterinary Journal, 20, 89-99.

Kristjanson, P., Waters-Bayer, A., Johnson, N., Tipilda, A., Njuki, J., Baltenweck, I,...\& MacMillian, S. (2010). Livestock and Women's livelihoods: A review of the recent evidence (Discussion Paper No. 20). Nairobi, Kenya: International Livestock Research Institute.

Lwelamira, J., Binamungu, H. K., \& Njau, F. B. (2010). Contribution of small scale dairy farming under zero-grazing in improving household welfare in Kayanga ward, Karagwe district, Tanzania. Livestock Research for Rural Development, 22(2). Retrieved fromhttp://www.lrrd.org/lrrd22/2/lwel22031.htm 
Matshe, I. (2009). Boosting smallholder production for food security: Some approaches and evidence from studies in sub-Saharan Africa. Agrekon, 48(4), 483-510. http://dx.doi.org/10.1080/03031853.2009.9523837

Moron, C. (2006). Food-based nutrition interventions at community level. The British Journal of Nutrition, 96 (Suppl. 1), S20-S22. http://dx.doi.org/10.1079/BJN20061693

Morris, S. M., Carletto, C., Hoddinott, J., \& Christiaensen, L. J. M. (2000). Validity of rapid estimates of household wealth and income for health surveys in rural Africa. Journal of Epidemiology and Community Health 54(5), 381-387. http://dx.doi.org/10.1136/jech.54.5.381

Mullins, G., Wahome, L., Tsangari, P., \& Maarse, L. (1996). Impacts of intensive dairy production on smallholder farm women in coastal Kenya. Human Ecology 24(2), 231-253. http://dx.doi.org/10.1007/BF02169128

Nicholson, C. F., Mwangi, L., Staal, S. J., \& Thornton, P. K. (2003). Dairy cow ownership and child nutritional status in Kenya. AAEA Annual Meetings, Montréal. Retrieved from http://ageconsearch. umn.edu/bitstream/22154/1/sp03ni01.pdf

Nicholson, C. F., Thornton, P. K. \& Muinga, R. W. (2004). Household-level impacts of dairy cow ownership in coastal Kenya. Journal of Agricultural Economics, 55(2), 175-195. http://dx.doi.org/ 10.1111/j.1477-9552.2004.tb00092.x

Njuki, J., Kaaira, S., Chamunorwa, A., \& Chiuri, W. (2011) Linking smallholder farmers to markets, gender and intra-household dynamics: Does the choice of commodity matter? European Journal of Development Research, 23(3), 426-443. http://dx.doi.org/10.1057/ejdr.2011.8

Penrod, J., Preston, D. B., Cain, R. E., \& Starks, M. T. (2003). A discussion of chain referral as a method of sampling hard-to-reach populations. Journal of Transcultural Nursing, 14(2), 100-107. http://dx.doi.org/10.1177/1043659602250614

PKF Consulting Ltd. \& International Research Network. (2005). Tea and coffee industry in Kenya. Kenya: Export Processing Zones Authority Kenya. Retrieved from http://www.epzakenya. com/UserFiles/File/Beverages.pdf

Sharma, K. L., \& Vanjani, U. (1993). When more means less: Assessing the impact of dairy "development" on the lives and health of women in rural Rajasthan
(India). Social Science and Medicine, 37(11), 1377-1389. http://dx.doi.org/10.1016/0277-9536(93)90168-4

Tangka, F., Ouma, E. A., \& Staal, S. J. (1999). Women and the sustainable development of marketoriented dairying: Evidence from the highlands of East Africa. Retrieved from: http://www.smallholderdairy.org/publications/ Conference/Tangka \%20et $\% 20$ al-1999Women $\% 20 \& \% 20$ dev $\% 20$ of $\% 20$ market $\% 20$ oriented $\% 20$ dairy-ISDRC.pdf

Tangka, F. K., Emerson, R. D., \& Jabbar, M. A. (2002). Food security effects of intensified dairying: Evidence from the Ethiopian highlands (Socio-Economics and Policy Research Working Paper No. 44). Retrieved from the International Livestock Research Institute website: http://www.ilri.org/InfoServ/Webpub/ fulldocs/InvestingInDairy/DOX/FoodSecurity IntensifiedDairy\%20WorkingPaper44.pdf

Thorpe, W., Muriuki, H. G., Omore, A., Owango, M. O., \& Staal, S. (2000). Dairy development in Kenya: The past, the present and the future. Retrieved from the International Livestock Research Institute website: http://cgspace.cgiar.org/handle/10568/1723

VanLeeuwen, J. A., Mellish, T., Walton, C., Kaniaru, A., Gachiru, R., Mellish, K., ...Wichtel, J. J. (2012). Management, productivity, and livelihood effects of Kenyan smallholder dairy farms from interventions addressing animal health and nutrition and milk quality. Tropical Animal Health and Production, 44(2), 231-238. http://dx.doi.org/10.1007/s11250-011-0003-2

Walingo, M. K. (2009). Role of livestock projects in empowering women smallholder farmers for sustainable food security in rural Kenya. African Journal of Food, Agriculture, Nutrition and Development, 9(7), 1468-1483. Retrieved from http://www. ajfand.net/Volume9/No7/index7.html

Walton, C. (2012). Sustainable livelihoods of smallholder dairy farmers in the Kenyan highlands (Doctoral dissertation). Atlantic Veterinary College, University of Prince Edward Island, Canada. Unpublished raw data.

Wamani, H., Tylleskär, T., Åstrøm, A. N., Tumwine, J. K., \& Peterson, S. (2004). Mothers' education but not fathers' education, household assets or land ownership is the best predictor of child health inequalities in rural Uganda. International Journal for Equity in Health, 3(1), 1-9. http://dx.doi.org/10.1186/1475-9276-3-9 
Wodon, Q., \& Zaman, H. (2010). Higher food prices in Sub-Saharan Africa: Poverty impact and policy responses. World Bank Research Observer, 25(1), 157-176. http://dx.doi.org/10.1093/wbro/lkp018

World Vision. (2012). World Vision Africa: Kenya: $\checkmark$ ulnerability to food shortages. Retrieved from http://www.wvafrica.org/index.php?option=com content\&view $=$ article\&id $=139 \&$ Itemid $=156$
Yisehak, K. (2008). Gender responsibility in smallholder mixed crop-livestock production systems of Jimma zone, South West Ethiopia. Livestock Research for Rural Development, 20(1). Retrieved from Livestock Research for Rural Development website: http://www.lrrd.org/lrrd20/1/yise20011.htm 